\title{
Omalizumab Effectiveness in Severe Allergic Asthma with Multiple Allergic Comorbidities: A Post-Hoc Analysis of the STELLAIR Study
}

\author{
Jocelyne Just $\mathbb{D}^{1-3}$ \\ Celine Thonnelier (iD) ${ }^{4}$ \\ Melisande Bourgoin-Heck ${ }^{5}$ \\ Laurence Mala ${ }^{4}$ \\ Mathieu Molimard (iD ${ }^{6}$ \\ Marc Humbert (iD ${ }^{7-9}$ \\ On behalf of the STELLAIR \\ Investigators
}

'Groupe Hospitalier Trousseau-La Roche Guyon, Service d'Allergologie, Paris, France; ${ }^{2}$ Université Paris Sorbonne, Paris, France; ${ }^{3}$ UMR III53 - Centre de Recherche en Épidémiologie et Statistiques (CRESS), Paris, France; ${ }^{4}$ Novartis Pharma, Rueil Malmaison, France; ${ }^{5}$ Hôpital Trousseau, Service d'Allergologie, Paris, France; ${ }^{6} \mathrm{CHU}$ de Bordeaux, Service de Pharmacologie Médicale, Bordeaux, France; ${ }^{7}$ Université Paris-Saclay, Faculté de Médecine, Le Kremlin-Bicêtre, France; ${ }^{8}$ AP-HP, Service de Pneumologie, Hôpital Bicêtre, Le Kremlin-Bicêtre, France; ' ${ }^{9}$ INSERM UMR_S 999, Hôpital Marie Lannelongue, Le Plessis Robinson, France
Correspondence: Jocelyne Just Service d'Allergologie, Groupe hospitalier Trousseau-La Roche Guyon, 26 Avenue du Dr. Arnold Netter, Paris, 750I2. France

Tel +33 | $7 \mid 736847$

Fax +33 | 447353 I5

Email jocelyne.just@aphp.fr
Background: Immunoglobulin (Ig) E-mediated pathophysiological mechanisms are common in allergic diseases including severe allergic asthma (SAA). The anti-IgE monoclonal antibody omalizumab may be particularly beneficial for patients with SAA and multiple allergic comorbidities (AC) including perennial/seasonal rhinitis, conjunctivitis, atopic dermatitis (AD), and food allergy.

Methods: We conducted a post-hoc analysis of the patients from the STELLAIR study ( $\mathrm{n}=872,149$ minors and 723 adults). The patients were classified based on the presence of multiple $\mathrm{AC}$ ( $\geq 3 \mathrm{AC}$ or $<3 \mathrm{AC}$ ) or $\mathrm{AD}$ as assessed by questionnaire. Response to omalizumab was assessed after 4-6 months $\left(\mathrm{T}_{4-6}\right)$ and after 12 months $\left(\mathrm{T}_{12}\right)$. Asthma response at $\mathrm{T}_{4-6}$ was based on global evaluation of treatment effectiveness, reduction of $\geq 40 \%$ in annual exacerbation rate, and a combination of both. Asthma response at $T_{12}$ was based on change in yearly exacerbation and hospitalization rates. $\mathrm{AC}$ improvement at $\mathrm{T}_{12}$ was based on patient perception.

Results: Patients with $\geq 3$ AC demonstrated a higher combined response to omalizumab (74.7\% vs $58.3 \%$ ) at $\mathrm{T}_{4-6}$ and had reduced yearly exacerbation and hospitalization rates ( $88.9 \%$ vs $77.4 \%$ and $-94.0 \%$ vs $-70.5 \%$, respectively). Patients with $\geq 3$ AC were more likely to show an improvement in their $\mathrm{AC}(85.3 \%$ vs $51.9 \%)$ at $\mathrm{T}_{12}$. Results were similar in minors and adults. The presence of $\mathrm{AD}$ was associated with greater omalizumab effectiveness at $\mathrm{T}_{4-6}$ and a greater $\mathrm{AC}$ improvement at $\mathrm{T}_{12}$. Improvement of $\mathrm{AD}$ and food allergies at $\mathrm{T}_{12}$ were $73.2 \%$ and $38.7 \%$, respectively, in the population overall.

Conclusion: This post-hoc analysis of the STELLAIR study shows that omalizumab is beneficial for all SAA patients and especially for patients with multiple AC or AD. In patients with $\geq 3 \mathrm{AC}$, omalizumab also improved $\mathrm{AC}$ outcomes.

Keywords: Ig-E, multiple allergic comorbidities, omalizumab, severe allergic asthma

\section{Plain Language Summary}

Patients with severe allergic asthma (SAA), and especially children, often have other allergic comorbidities, such as conjunctivitis, rhinitis, dermatitis, and food allergy. We conducted a post-hoc analysis of the real-life STELLAIR study to investigate the relevance of omalizumab, a recombinant humanized IgG1 monoclonal antibody, in adults and minors with SAA and allergic comorbidities. We demonstrated that omalizumab is more effective in patients with multiple allergic comorbidities. Our results confirm that the inhibition of IgE-mediated pathways may have a broad effect that goes beyond the control of SAA and could be useful in helping physicians decide on the optimal treatment for their patients with severe allergic asthma. 


\section{Introduction}

Approximately $5-10 \%$ of patients with asthma have severe disease with uncontrolled or partially controlled symptoms despite intensive treatment. ${ }^{1}$ The burden of severe asthma is high in terms of mortality, comorbidities and healthcare resources. $^{2}$

From a clinical point of view, severe asthma is a heterogeneous disease with different phenotypes, such as eosinophilic and allergic asthma. ${ }^{1,3}$ Immunoglobulin (Ig) E plays a key role in the pathogenesis of severe allergic asthma (SAA), as they are known to participate in immediate hypersensitivity responses in the airways and in the induction of chronic allergic bronchial inflammation. ${ }^{4,5}$

Allergic asthma often coexists with other allergic diseases that share the same underlying IgE-mediated pathophysiological mechanism. ${ }^{6}$ Therefore, IgE-mediated pathways represent an attractive target for the treatment of both allergic asthma and related allergic comorbidities (AC).

Severe asthma with multiple AC and high IgE levels is particularly prevalent in children. Multiple AC have been observed in children with high specific IgE levels and with severe asthma from different birth cohorts. ${ }^{7}$ Similarly, in an inner-city cohort of children, those with the most symptomatic asthma with Global Initiative for Asthma (GINA) Steps 4 and 5 exhibited multiple AC and higher total serum IgE levels (median $733 \mathrm{kU} / \mathrm{L}$ ) compared with children in less symptomatic clusters. ${ }^{8}$

Omalizumab is a recombinant humanized IgG1 monoclonal antibody that binds to the $\mathrm{C} 3$ domain of IgE preventing interaction with the cognate receptor, and ultimately reducing the allergic response and inflammation. Omalizumab is indicated as an add-on treatment for patients $\geq 6$ years old with uncontrolled persistent SAA. It is also known to be effective in a variety of IgE-mediated diseases. $^{4,9-20}$

The STELLAIR (Next Steps Towards personalised care: EvaLuating responders to XoLAIR treatment in patients with SAA) study assessed the value of pretreatment peripheral blood eosinophil counts as a predictive measure for response to omalizumab. ${ }^{21}$ Results of the STELLAIR study showed that omalizumab effectiveness was similar in SAA irrespective of eosinophil counts. Another study was conducted to identify predictive markers of response to omalizumab in a cohort of children $(n=45)$ with SAA treated with omalizumab for at least 4 months. ${ }^{22}$ Results of this study identified atopic dermatitis (AD) as a predictive factor to complete response to omalizumab. In addition, they suggested that the presence of multiple AC and multiple sensitizations $(\geq 2)$ were associated with the complete response to omalizumab.

This article presents the results of a post-hoc analysis of the data from the STELLAIR study aimed at investigating the possible impact of multiple $\mathrm{AC}$ and $\mathrm{AD}$ on omalizumab effectiveness in adults and minors with SAA, and the effect of omalizumab on AC.

\section{Materials and Methods Study Design and Participants}

STELLAIR was a multicenter, non-interventional, retrospective, observational study conducted in France from December 21, 2015 to September 30, 2016. The methods and results of this study have been previously published in ERJ by Humbert et al., 2018. ${ }^{21}$ Hospital-based pulmonologists and pediatric pulmonologists provided data collected from patients with SAA treated with omalizumab (up to 30 consecutive patients per physician) who complied with the study inclusion criteria. Patients were $\geq 6$ years old; had been treated with omalizumab for poorly controlled SAA; had recorded value of blood eosinophilia and number of exacerbations within the year prior to omalizumab initiation; and had a documented physician evaluation of response to omalizumab and number of exacerbations recorded after 4-6 months of treatment. The study was conducted in accordance with the Declaration of Helsinki and approved by the institutional committees in charge of data protection in biomedical research in France (Comité Consultatif sur le Traitement de l'Information en matière de Recherche and Commission Nationale de l'Informatique et des Libertés). Patients who refused collection of their medical data for research purposes were excluded in line with the ethics committee requirements. Parent or legal guardian of minors provided informed consent.

For all patients, omalizumab was prescribed as an addon therapy to high-dose inhaled corticosteroids, plus a long-acting $\beta_{2}$-agonist with or without oral corticosteroids (OCSs). ${ }^{21}$

The study was completed using retrospective secondary patient data recorded in electronic case report forms. Data collected were analyzed at 4-6 months $\left(\mathrm{T}_{4-6}\right.$, first effectiveness assessment as required by the omalizumab summary of product characteristics) and 12 months ( $\mathrm{T}_{12}$, 
for renewal of prescription, if available) following treatment initiation.

Since STELLAIR was a retrospective noninterventional study, it did not require registration on ClinicalTrials.gov.

\section{Multiple AC}

We included the following allergic diseases as AC: conjunctivitis, perennial or seasonal allergic rhinitis (AR), AD, and food allergy. A patient was classified as having multiple $\mathrm{AC}$ if they presented with $\geq 3 \mathrm{AC}$ besides perennial or seasonal AR which were present in $>80 \%$ of the patients in the study.

\section{Asthma Outcomes}

Response to omalizumab treatment at $\mathrm{T}_{4-6}$ was assessed using three criteria:

1. The physician's overall evaluation according to the Global Evaluation of Treatment Effectiveness (GETE). GETE is a five-point scale with lower points indicating a better asthma control: $1=$ excellent (complete asthma control), 2=good (marked improvement), $3=$ moderate (discernible but limited improvement), 4=poor (no appreciable change), $5=$ worsening. Patients with scores of 1 and 2 were considered as "responders", while those with scores of 3, 4 or 5 were considered as "non-responders".

2. Annual exacerbation rate. An asthma exacerbation was defined as a significant worsening of asthma requiring either a short burst of OCSs or an increase in the OCS dose regimen for patients treated with an OCS. Patients were considered as "responders" when they exhibited a reduction in annual exacerbation rate of $\geq 40 \%$.

3. A combination of the GETE and a $\geq 40 \%$ reduction in the annual exacerbation rate ("combined response").

At $\mathrm{T}_{12}$, omalizumab effects on yearly exacerbation and hospitalization rates were assessed.

\section{AC Outcome}

The presence of AC was assessed at treatment initiation. To gauge comorbidity improvement at $T_{12}$, physicians were asked the following Yes/No question based on the patient's chart: "Have you observed any improvement in comorbidities since omalizumab initiation?". If the answer was positive (Yes), they were asked to specify which of the comorbidities had improved.

\section{Statistical Analysis}

Statistical analyses were performed using the SAS version 9.4 (SAS Institute, Cary, NC, USA). Sub-analyses were performed by age (minors: 6-17 years old; adults: $\geq 18$ years old), presence of $\mathrm{AC}$ ( $\geq 3 \mathrm{AC}$ or $<3 \mathrm{AC}$ ), and presence of AD (Yes/No). Of note, since AR (perennial or seasonal) was present in $>80 \%$ of cases (see Table 1), patients with multiple AC were defined as those presenting with $\geq 3$ AC. For qualitative variables, the number and percentage of patients are presented. For quantitative variables, the number of patients, mean and standard deviation (SD) are presented. For the asthma outcomes at $\mathrm{T}_{4-6}$, the 95\% confidence intervals (CIs) are indicated.

Univariate and multivariate regression analyses were performed to identify potential surrogates for response to omalizumab. Factors tested included: age at omalizumab initiation, sex, total serum $\operatorname{IgE}$ levels, blood eosinophil count, number of $\mathrm{AC}$ at omalizumab initiation $(\geq 3$, $<3)$, AD at omalizumab initiation, and number of asthma exacerbations in the year before omalizumab initiation. Only the significant factors identified in the univariate analysis $(\mathrm{p}<0.10)$ were introduced in the multivariate analysis.

\section{Results \\ Patient Disposition}

Of the 879 patients meeting the inclusion/exclusion criteria, 872 were included in the analysis at $\mathrm{T}_{4-6}$ and 706 at $\mathrm{T}_{12}$ (Figure 1). Of note, the lower number of patients at $\mathrm{T}_{12}$ was because a visit was not mandatory at 12 months.

\section{Demographic and Clinical Characteristics at Baseline}

All patients included in the study had SAA, exhibiting approximately five exacerbations and two hospitalizations in the year before omalizumab initiation (Table 1). $\operatorname{IgE}$ levels and blood eosinophil count in the year before omalizumab initiation were generally higher in minors than adults.

The mean age of omalizumab initiation was lower in adults with $\geq 3 \mathrm{AC}$ than with $<3 \mathrm{AC}(39.3 \pm 14.19$ vs 51.4 \pm 13.96 years), and similar in minors with $\geq 3$ or $<3$ AC (11.3 \pm 2.97 and $11.5 \pm 3.12$ years, respectively).

A high proportion of patients had at least one AC (Table 1). More minors than adults presented with $\geq 3$ 
Table I Demographic and Clinical Characteristics at Baseline

\begin{tabular}{|c|c|c|c|c|c|c|}
\hline & \multicolumn{2}{|c|}{ Minors $\mathrm{N}=149$} & \multicolumn{2}{|c|}{ Adults $\mathbf{N}=723$} & \multicolumn{2}{|c|}{$\begin{array}{l}\text { Total (Minors and Adults) } \\
\qquad \mathbf{N}=872\end{array}$} \\
\hline & $<3 \mathrm{AC}$ & $\geq 3 \mathrm{AC}$ & $<3 \mathrm{AC}$ & $\geq 3 \mathrm{AC}$ & $<3 \mathrm{AC}$ & $\geq 3 \mathrm{AC}$ \\
\hline N (\%) & $105(70.5)$ & $44(29.5)$ & $684(94.6)$ & $39(5.4)$ & $789(90.5)$ & $83(9.5)$ \\
\hline \multicolumn{7}{|l|}{ Sex, n (\%) } \\
\hline Male & $59(56.2)$ & $35(79.5)$ & 273 (39.9) & $10(25.6)$ & $332(42.1)$ & $45(54.2)$ \\
\hline Female & $46(43.8)$ & $9(20.5)$ & $4 I I(60.1)$ & $29(74.4)$ & $457(57.9)$ & $38(45.8)$ \\
\hline \multicolumn{7}{|l|}{$\begin{array}{l}\text { Age at omalizumab initiation, } \\
\text { years }\end{array}$} \\
\hline Mean $\pm S D$ & $11.5 \pm 3.12$ & $11.3 \pm 2.97$ & $51.4 \pm 13.96$ & $39.3 \pm 14.19$ & $46.1 \pm 18.82$ & $24.5 \pm 17.20$ \\
\hline \multicolumn{7}{|l|}{ Allergic Comorbidities, n (\%) } \\
\hline Yes & $90(85.7)$ & $44(100.0)$ & $360(52.6)$ & $39(100.0)$ & $450(57.0)$ & $83(100.0)$ \\
\hline Perennial rhinitis & $67(74.4)$ & $41(93.2)$ & $263(73.1)$ & $37(94.9)$ & $330(73.3)$ & $78(94.0)$ \\
\hline Seasonal rhinitis & $25(27.8)$ & $30(68.2)$ & $82(22.8)$ & $24(61.5)$ & $107(23.8)$ & $54(65.1)$ \\
\hline Conjunctivitis & II (I2.2) & $20(45.5)$ & $49(13.6)$ & $36(92.3)$ & $60(13.3)$ & $56(67.5)$ \\
\hline Atopic dermatitis & $17(18.9)$ & $33(75.0)$ & $23(6.4)$ & $17(43.6)$ & $40(8.9)$ & $50(60.2)$ \\
\hline Food allergy & $9(10.0)$ & $28(63.6)$ & $24(6.7)$ & $16(41.0)$ & $33(7.3)$ & $44(53.0)$ \\
\hline \multicolumn{7}{|l|}{ Number of exacerbations ${ }^{\dagger}$} \\
\hline $\mathrm{n}$ & 105 & 44 & 684 & 39 & 789 & 83 \\
\hline Mean \pm SD & $5.2 \pm 4.03$ & $5.2 \pm 3.51$ & $4.3 \pm 3.08$ & $4.2 \pm 2.74$ & $4.5 \pm 3.24$ & $4.7 \pm 3.19$ \\
\hline \multicolumn{7}{|l|}{ Number of hospitalisations ${ }^{\dagger}$} \\
\hline n & 58 & 21 & 281 & 14 & 339 & 35 \\
\hline Mean \pm SD & $2.3 \pm 1.87$ & $2.1 \pm 2.17$ & $1.7 \pm 1.39$ & $1.6 \pm 0.85$ & $1.8 \pm 1.50$ & $1.9 \pm 1.77$ \\
\hline \multicolumn{7}{|l|}{ Total serum IgE, IU/mL } \\
\hline $\mathrm{n}$ & 104 & 44 & 645 & 38 & 749 & 82 \\
\hline Mean $\pm S D$ & || $98.8 \pm|4| 2.85$ & $1744.2 \pm \mid 445.2$ & $512.5 \pm 752.00$ & $801.7 \pm 1351.82$ & $607.8 \pm 904.52$ & $|307.4 \pm| 472.1 \mid$ \\
\hline \multicolumn{7}{|l|}{ Blood eosinophil count ${ }^{\dagger}$, cells $/ \mu L$} \\
\hline $\mathrm{n}$ & 105 & 44 & 684 & 39 & 789 & 83 \\
\hline Mean \pm SD & $667.1 \pm 525.87$ & $726.4 \pm 464.02$ & $457.5 \pm 6 \mid 4.34$ & $328.3 \pm 224.44$ & $485.4 \pm 607.20$ & $593.3 \pm 419.76$ \\
\hline
\end{tabular}

Note: ${ }^{\dagger}$ One year before omalizumab initiation.

Abbreviations: AC, allergic comorbidities; Ig, immunoglobulin; SD, standard deviation.

AC: $44 / 149$ (29.5\%) vs 39/723 (5.4\%). Among nonrespiratory $\mathrm{AC}, \mathrm{AD}$ was the most common.

Notably, the proportion of patients suffering from AD and food allergies was greater in minors than adults (33.6\% vs $5.5 \%$ and $24.8 \%$ vs $5.5 \%$, respectively), and greater in patients with $\geq 3 \mathrm{AC}$ than $<3 \mathrm{AC}$ (minors: $75.0 \%$ vs $18.9 \%$ and $63.6 \%$ vs $10.0 \%$, respectively; adults: $43.6 \%$ vs $6.4 \%$ and $41.0 \%$ vs $6.7 \%$, respectively).

\section{Omalizumab Effectiveness at $T_{4-6}$ and $T_{12}$ in Patients with $\geq 3$ or $\leq 3 \mathrm{AC}$} Asthma Outcomes

At $\mathrm{T}_{4-6}$, a majority of patients were classified as responders to omalizumab based on the three criteria used to test effectiveness. Overall, more responders were observed in the patients with $\geq 3 \mathrm{AC}$ than in those with $<3 \mathrm{AC}$ (ie, GETE score: $83.1 \%$ vs $67.4 \%$, change in yearly exacerbation rate: $85.5 \%$ vs $71.0 \%$, and combined response: $74.7 \%$ vs 58.3\%) (Table 2 and Figure 2, Panel A). Similar results were observed in adults and minors.

A univariate analysis revealed that response to omalizumab at $\mathrm{T}_{4-6}$ was associated with the following factors at omalizumab initiation: age $(\mathrm{p}=0.025)$, total serum $\operatorname{IgE}$ levels ( $\mathrm{p}=0.001)$, blood eosinophil count ( $\mathrm{p}=0.036$ ), number of $\mathrm{AC}(<3 \mathrm{vs} \geq 3$; $\mathrm{p}=0.003)$ and $\mathrm{AD}(\mathrm{Yes} / \mathrm{No} ; \mathrm{p}=0.031)$ for the overall population; total serum $\operatorname{IgE}(\mathrm{p}=0.090)$ and blood eosinophil count $(\mathrm{p}=0.033)$ for minors; total serum $\operatorname{IgE}(\mathrm{p}=0.024)$ and number of $\mathrm{AC}(\mathrm{p}=0.017)$ for adults.

A multivariate analysis revealed that presence of $\geq 3 \mathrm{AC}$ (ie, multiple AC) at omalizumab initiation was a surrogate of 


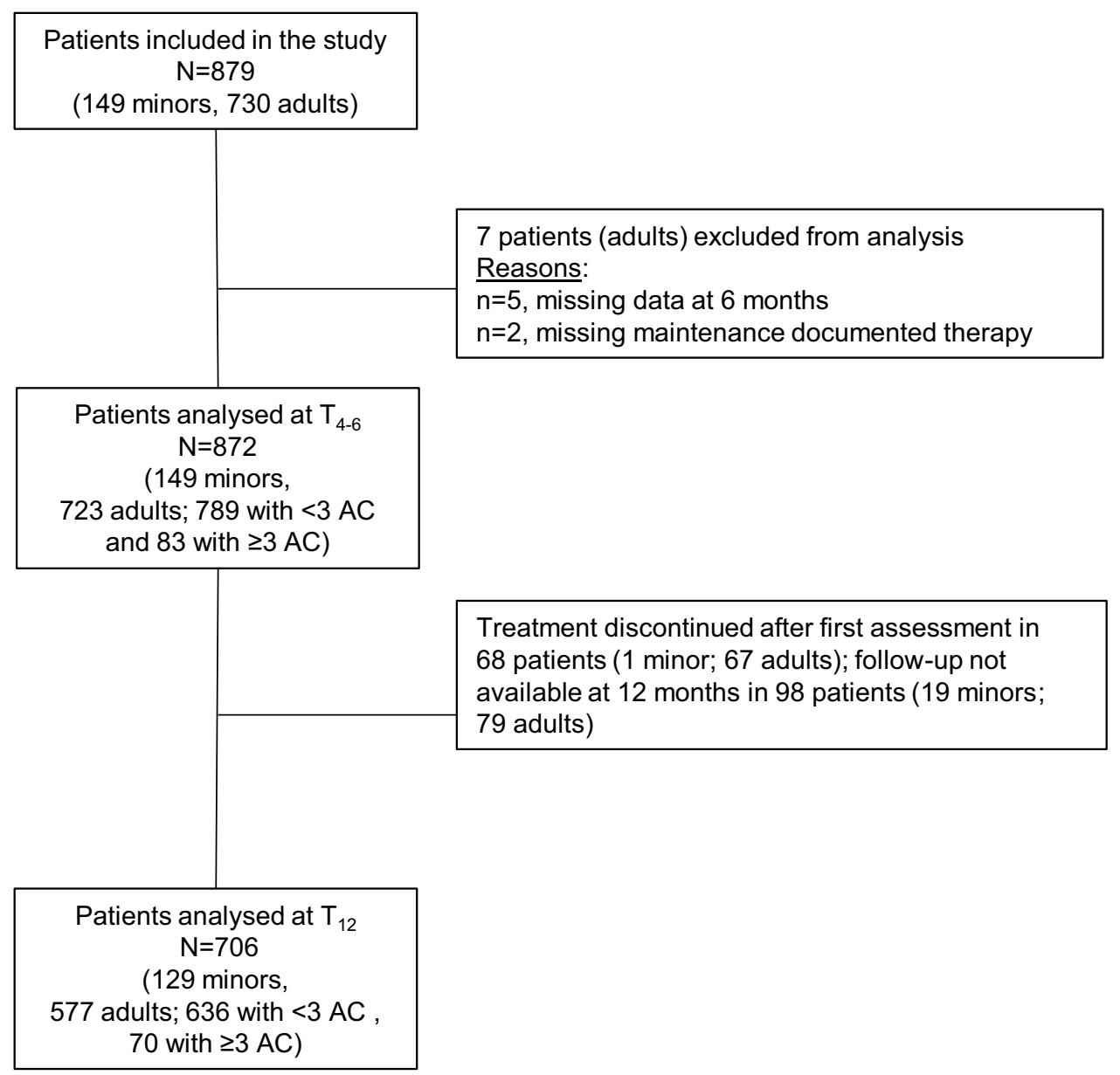

Figure I Patients disposition.

Abbreviations: AC, allergic comorbidities; $T_{4-6}, 4-6$ months; $T_{12}, 12$ months.

response to omalizumab at $\mathrm{T}_{4-6}$ in the overall population and adults (odds ratio: 2.304 [ $\mathrm{p}=0.0060]$ and $2.685[\mathrm{p}=0.0291]$, respectively) (Figure 3).

At $\mathrm{T}_{12}$, omalizumab was more effective in patients with $\geq 3 \mathrm{AC}$ than in those with $<3 \mathrm{AC}$ in the overall population in terms of change in yearly exacerbation rate (responders: $88.9 \%$ vs $77.4 \%$ ) and change in the yearly hospitalization rate related to asthma $(-94.0 \% \pm 26.04$ vs $-70.5 \% \pm 56.22)$ (Table 2). Similar results were observed in minors and adults.

At $\mathrm{T}_{12}$, a general improvement in AC after omalizumab initiation was observed in 94/115 (81.7\%) minors and 154/ 319 (48.3\%) adults; in particular, AC improvement was observed in more patients with $\geq 3 \mathrm{AC}$ than in those with $<3 \mathrm{AC}$ in the overall population ( $85.3 \%$ vs $51.9 \%)$, minors $(91.9 \%$ vs $76.9 \%)$ and adults ( $77.4 \%$ vs $45.1 \%)$ (Table 2$)$.

\section{AC Outcome}

In the overall population, the proportions of minors with $\mathrm{AD}$ or food allergies at omalizumab initiation who improved these comorbidities at $\mathrm{T}_{12}$ were $73.2 \%$ and $38.7 \%$, respectively; the corresponding proportions of adults were $24.1 \%$ and $16.1 \%$, respectively (data not shown).

\section{Omalizumab Effectiveness at $T_{4-6}$ and $T_{12}$ in Patients with or without AD}

At $\mathrm{T}_{4-6}$, in the overall population, there were more responders among patients with $\mathrm{AD}$ than among those without AD for GETE score (78.9\% vs $67.8 \%$ ), change in yearly exacerbation rate $(80.0 \%$ vs $71.5 \%)$, and combined response (71.1\% vs 58.6\%) (Table 3 and Figure 2, Panel B). Similar results were obtained in minors and, to a lesser extent, in adults.

At $T_{12}$, there was a greater proportion of yearly exacerbation rate responders in patients with $\mathrm{AD}$ vs those without $\mathrm{AD}$ for the overall population $(87.5 \%$ vs $77.2 \%)$, minors $(90.9 \%$ vs $79.7 \%)$, and less so for adults $(80.0 \%$ vs $76.6 \%$ ) (Table 3). There were no differences in terms of change in yearly hospitalization rates related to asthma 
Table 2 Omalizumab Effectiveness at $\mathrm{T}_{4-6}$ and $\mathrm{T}_{12}$ in Patients with $<3$ or $\geq 3 \mathrm{AC}$

\begin{tabular}{|c|c|c|c|c|c|c|}
\hline & \multicolumn{2}{|c|}{ Minors } & \multicolumn{2}{|c|}{ Adults } & \multicolumn{2}{|c|}{ Total (Minors and Adults) } \\
\hline & $<3 \mathrm{AC}$ & $\geq 3 \mathrm{AC}$ & $<3 \mathrm{AC}$ & $\geq 3 \mathrm{AC}$ & $<3 \mathrm{AC}$ & $\geq 3 \mathrm{AC}$ \\
\hline $\mathbf{T}_{4-6}, \mathbf{N}$ & 105 & 44 & 684 & 39 & 789 & 83 \\
\hline $\begin{array}{l}\text { GETE score } \\
\text { Responders, n (\%) } \\
{[95 \% \mathrm{Cl}]}\end{array}$ & $\begin{array}{c}79(75.2) \\
{[66.98 ; 83.49]}\end{array}$ & $\begin{array}{c}36(81.8) \\
{[70.42 ; 93.21]}\end{array}$ & $\begin{array}{c}453(66.2) \\
{[62.68 ; 69.77]}\end{array}$ & $\begin{array}{c}33(84.6) \\
{[73.29 ; 95.94]}\end{array}$ & $\begin{array}{c}532(67.4) \\
{[64.16 ; 70.70]}\end{array}$ & $\begin{array}{c}69(83.1) \\
{[75.08 ; 91.19]}\end{array}$ \\
\hline $\begin{array}{l}\text { Change in yearly asthma exacerbation rate } \\
\text { Responders, } n(\%) \\
{[95 \% \mathrm{Cl}]}\end{array}$ & $\begin{array}{c}78(74.3) \\
{[65.93 ; 82.65]}\end{array}$ & $\begin{array}{c}39(88.6) \\
{[79.26 ; 98.01]}\end{array}$ & $\begin{array}{c}482(70.5) \\
{[67.05 ; 73.89]}\end{array}$ & $\begin{array}{c}32(82.1) \\
{[70.01 ; 94.10]}\end{array}$ & $\begin{array}{c}560(71.0) \\
{[67.81 ; 74.14]}\end{array}$ & $\begin{array}{c}71(85.5) \\
{[77.98 ; 93.11]}\end{array}$ \\
\hline$T_{12}, N$ & 92 & 37 & 544 & 33 & 636 & 70 \\
\hline $\begin{array}{l}\text { Yearly rate of asthma exacerbation } \\
\mathrm{n} \\
\text { Mean } \pm S D\end{array}$ & $\begin{array}{c}63 \\
1.2 \pm 1.58\end{array}$ & $\begin{array}{c}29 \\
1.0 \pm 1.71\end{array}$ & $\begin{array}{c}282 \\
I .4 \pm 2.0 \mathrm{I}\end{array}$ & $\begin{array}{c}7 \\
0.6 \pm 0.59\end{array}$ & $\begin{array}{c}345 \\
1.4 \pm 1.94\end{array}$ & $\begin{array}{c}36 \\
0.9 \pm 1.56\end{array}$ \\
\hline $\begin{array}{l}\text { Change in yearly asthma exacerbation rate } \\
\mathrm{n} \\
\text { Responders, } \mathrm{n}(\%)\end{array}$ & $\begin{array}{c}63 \\
51(81.0)\end{array}$ & $\begin{array}{c}29 \\
26(89.7)\end{array}$ & $\begin{array}{c}282 \\
216(76.6)\end{array}$ & $\begin{array}{c}7 \\
6(85.7)\end{array}$ & $\begin{array}{c}345 \\
267(77.4)\end{array}$ & $\begin{array}{c}36 \\
32(88.9)\end{array}$ \\
\hline $\begin{array}{l}\text { Yearly rate of hospitalization } \\
\mathrm{n} \\
\text { Mean } \pm S D\end{array}$ & $\begin{array}{c}90 \\
0.3 \pm 0.74\end{array}$ & $\begin{array}{c}37 \\
0.0 \pm 0.13\end{array}$ & $\begin{array}{c}536 \\
0.2 \pm 0.62\end{array}$ & $\begin{array}{c}32 \\
0.0 \pm 0.24\end{array}$ & $\begin{array}{c}626 \\
0.2 \pm 0.64\end{array}$ & $\begin{array}{c}69 \\
0.0 \pm 0.19\end{array}$ \\
\hline $\begin{array}{l}\text { Change in yearly hospitalisation rate } \\
\mathrm{n} \\
\text { Mean } \pm \mathrm{SD}\end{array}$ & $\begin{array}{c}52 \\
-64.6 \% \pm 60.55\end{array}$ & $\begin{array}{c}18 \\
-97.9 \% \pm 9.09\end{array}$ & $\begin{array}{c}223 \\
-71.9 \% \pm 55.22\end{array}$ & $\begin{array}{c}11 \\
-87.6 \% \pm 41.06\end{array}$ & $\begin{array}{c}275 \\
-70.5 \% \pm 56.22\end{array}$ & $\begin{array}{c}29 \\
-94.0 \% \pm 26.04\end{array}$ \\
\hline $\begin{array}{l}\text { Improvement in AC after omalizumab initiation }{ }^{\dagger} \\
\mathrm{n} \\
\text { Yes, } \mathrm{n}(\%)\end{array}$ & $\begin{array}{c}78 \\
60(76.9)\end{array}$ & $\begin{array}{c}37 \\
34(91.9)\end{array}$ & $\begin{array}{c}288 \\
130(45.1)\end{array}$ & $\begin{array}{c}31 \\
24(77.4)\end{array}$ & $\begin{array}{c}366 \\
190(51.9)\end{array}$ & $\begin{array}{c}68 \\
58(85.3)\end{array}$ \\
\hline
\end{tabular}

Note: ${ }^{\dagger}$ Only patients with $\mathrm{AC}$ at omalizumab initiation are included in the analysis.

Abbreviations: $\mathrm{Cl}$, confidence interval; AC, allergic comorbidities; GETE, Global Evaluation of Treatment Effectiveness; SD, standard deviation; $\mathrm{n}$, patients with available data.

between patients with $\mathrm{AD}$ and those without for the overall population. In minors, a greater improvement was shown in patients with $\mathrm{AD}$ than those without $\mathrm{AD}$ $(-87.8 \% \pm 28.73$ vs $-67.3 \pm 60.85)$, while the opposite was observed in adults $(-49.2 \% \pm 80.77$ vs $-74.3 \% \pm 52.10)$ (Table 3).

At $\mathrm{T}_{12}$, a general improvement in $\mathrm{AC}$ after omalizumab initiation was observed in more patients with $A D$ vs those without $\mathrm{AD}$ in the overall population and minors $(68.6 \%$ vs $54.9 \%$ and $87.8 \%$ vs $78.4 \%$ ) but not in adults (Table 3 ).

\section{Discussion}

This article presents the results of a post-hoc analysis of data collected in the STELLAIR cohort to assess the impact of $\mathrm{AC}(\geq 3$ or $<3)$ on omalizumab effectiveness.

As previously reported, ${ }^{23}$ a high proportion of the patients with SAA $(>80 \%)$ treated with omalizumab in our study presented with allergic and non-allergic comorbidities. Our results confirm that the inhibition of IgE-mediated pathways may have a broad effect that goes beyond the control of SAA. ${ }^{24,25}$ However, the main results of the analyses we present here suggest that the presence of $\geq 3 \mathrm{AC}$ may be associated with a better performance of omalizumab in real-life settings. Compared to patients with $<3 \mathrm{AC}$, patients with $\geq 3 \mathrm{AC}$ had a greater short-term $\left(\mathrm{T}_{4-6}\right)$ and longterm $\left(\mathrm{T}_{12}\right)$ asthma response to omalizumab. In addition, they exhibited a greater improvement in AC. In line with these observations, presence of $\geq 3 \mathrm{AC}$ at omalizumab initiation was identified as a surrogate of response to omalizumab in the overall population and adults. These results are in line with those reported in a small cohort of children with SAA, which showed that multiple AC are necessary for a complete asthma response to omalizumab. ${ }^{22}$ Overall, these results confirm the importance of considering the presence of comorbidities when choosing treatment for severe asthma. ${ }^{26}$

In our study, special attention was given to $\mathrm{AD}$ and food allergies, as they were the only non-respiratory $\mathrm{AC}$ 


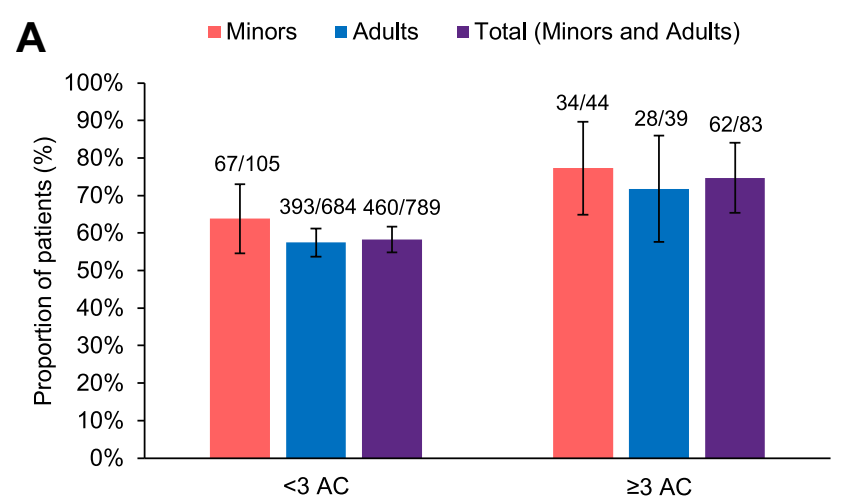

B

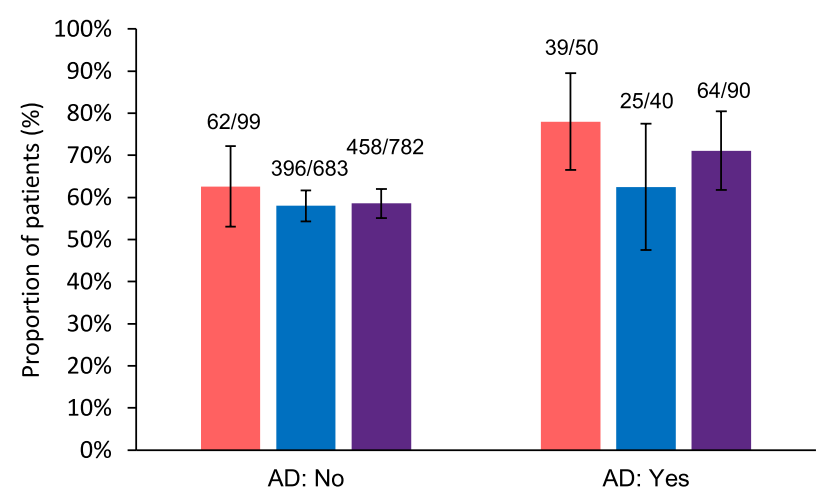

Figure 2 Responders to omalizumab treatment in minors, adults and total population (minors and adults) at $\mathrm{T}_{4-6}$ based on combined criteria (combination of GETE and exacerbation rate decrease) according to $<3 A C$ or $\geq 3 A C$ (Panel $\mathbf{A}$ ) and $A D$ : no/yes (Panel B). AD: no = absence of $A D$ at omalizumab initiation; $A D$ : yes = presence of $A D$ at omalizumab initiation. Error bars indicate $95 \% \mathrm{Cl}$.

Abbreviations: $A C$, allergic comorbidities; $A D$, atopic dermatitis; $\mathrm{Cl}$, confidence interval; $T_{4-6}, 4-6$ months.

reported in the STELLAIR cohort. AD is of greater interest as it is a recognized gateway for the development of allergies, especially food allergy; this pathway has been previously described as "atopic march". Our results suggest that omalizumab may improve these two conditions, and more so in children than in adults. This may be relevant as $\mathrm{AD}$ and food allergies were more common in minors. There are ongoing investigations in food allergy ${ }^{27}$ and published studies in $\mathrm{AD}^{28}$ reporting the beneficial effect of omalizumab on IgE-mediated diseases, providing a strong rationale for the use of omalizumab in this context. In addition, omalizumab has been designated as a Breakthrough Therapy by the Food and Drug Administration for the prevention of severe food allergy reactions after accidental exposure. Particularly in children, improvement of $\mathrm{AD}$ with omalizumab has been reported in various case series, ${ }^{29}$ while AD has also been identified as a predictive factor of complete response to omalizumab. $^{22}$ The present results support the fact that omalizumab may be effective in the treatment of these IgE-mediated diseases, especially in minors, and encourage further studies to support these findings.

The analyses presented in this report are mostly descriptive, representing a limitation of the study. In addition, the comorbidity improvement was assessed based on patients' charts. Despite these limitations, it is important to note that the reported data are from the real-world setting and as such they have an added value compared to data from controlled clinical studies, where patients' characteristics have to satisfy strict criteria. In addition, the STELLAIR cohort represents one of the biggest cohorts worldwide of SAA patients treated with omalizumab. Although not robust from a statistical point of view and
Number of $A C$ at omalizumab initiation, $<3 A C$ vs. $\geq 3 A C$

Total (Minors and Adults)

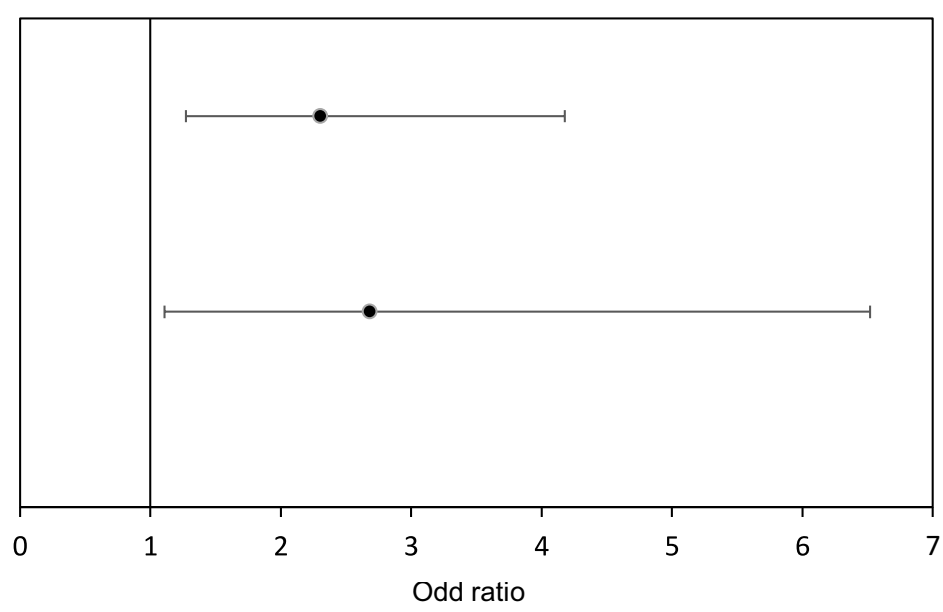

Odds ratio $[\mathrm{Cl}], \mathrm{p}$-value

2.304 [1.2706; 4.1789], 0.0060

$2.685[1.1059 ; 6.5201], 0.0291$

Figure 3 Responders to omalizumab treatment at 4-6 months for adults and total population (minors and adults) based on the presence of $\geq 3$ AC (ie multiple AC), in multivariate analysis.

Abbreviations: $\mathrm{AC}$, allergic comorbidities; $\mathrm{Cl}$, confidence interval; $\mathrm{T}_{4-6}, 4-6$ months. 
Table 3 Omalizumab Effectiveness at $T_{4-6}$ and $T_{12}$ in Patients without or with $A D$

\begin{tabular}{|c|c|c|c|c|c|c|}
\hline & \multicolumn{2}{|c|}{ Minors } & \multicolumn{2}{|c|}{ Adults } & \multicolumn{2}{|c|}{ Total (Minors and Adults) } \\
\hline & AD: No & AD: Yes & AD: No & AD: Yes & AD: No & AD: Yes \\
\hline $\mathbf{T}_{4-6}, \mathbf{N}$ & 99 & 50 & 683 & 40 & 782 & 90 \\
\hline $\begin{array}{l}\text { GETE score } \\
\text { Responders, n (\%) } \\
{[95 \% \mathrm{Cl}]}\end{array}$ & $\begin{array}{c}73(73.7) \\
{[65.07 ; 82.4 \mathrm{I}]}\end{array}$ & $\begin{array}{c}42(84.0) \\
{[73.84 ; 94.16]}\end{array}$ & $\begin{array}{c}457(66.9) \\
{[63.38 ; 70.44]}\end{array}$ & $\begin{array}{c}29(72.5) \\
{[58.66 ; 86.34]}\end{array}$ & $\begin{array}{c}530(67.8) \\
{[64.50 ; 71.05]}\end{array}$ & $\begin{array}{c}71(78.9) \\
{[70.46 ; 87.32]}\end{array}$ \\
\hline $\begin{array}{l}\text { Change in yearly asthma exacerbation rate } \\
\text { Responders, } \mathrm{n}(\%) \\
{[95 \% \mathrm{Cl}]}\end{array}$ & $\begin{array}{c}73(73.7) \\
{[65.07 ; 82.41]}\end{array}$ & $\begin{array}{c}44(88.0) \\
{[78.99 ; 97.01]}\end{array}$ & $\begin{array}{c}486(71.2) \\
{[67.76 ; 74.55]}\end{array}$ & $\begin{array}{c}28(70.0) \\
{[55.80 ; 84.20]}\end{array}$ & $\begin{array}{c}559(71.5) \\
{[68.32 ; 74.65]}\end{array}$ & $\begin{array}{c}72(80.0) \\
{[71.74 ; 88.26]}\end{array}$ \\
\hline$T_{12}, N$ & 88 & 41 & 546 & 31 & 634 & 72 \\
\hline $\begin{array}{l}\text { Yearly rate of asthma exacerbation } \\
\mathrm{n} \\
\text { Mean } \pm S D\end{array}$ & $\begin{array}{c}59 \\
1.2 \pm 1.60\end{array}$ & $\begin{array}{c}33 \\
1.0 \pm 1.66\end{array}$ & $\begin{array}{c}274 \\
1.4 \pm 2.02\end{array}$ & $\begin{array}{c}15 \\
1.1 \pm 1.61\end{array}$ & $\begin{array}{c}333 \\
1.4 \pm 1.95\end{array}$ & $\begin{array}{c}48 \\
1.0 \pm 1.63\end{array}$ \\
\hline $\begin{array}{l}\text { Change in yearly asthma exacerbation rate } \\
\mathrm{n} \\
\text { Responders, } \mathrm{n}(\%)\end{array}$ & $\begin{array}{c}59 \\
47(79.7)\end{array}$ & $\begin{array}{c}33 \\
30(90.9)\end{array}$ & $\begin{array}{c}274 \\
210(76.6)\end{array}$ & $\begin{array}{c}15 \\
12(80.0)\end{array}$ & $\begin{array}{c}333 \\
257(77.2)\end{array}$ & $\begin{array}{c}48 \\
42(87.5)\end{array}$ \\
\hline $\begin{array}{l}\text { Yearly rate of hospitalisation } \\
\mathrm{n} \\
\text { Mean } \pm \text { SD }\end{array}$ & $\begin{array}{c}87 \\
0.2 \pm 0.60\end{array}$ & $\begin{array}{c}40 \\
0.2 \pm 0.73\end{array}$ & $\begin{array}{c}537 \\
0.2 \pm 0.58\end{array}$ & $\begin{array}{c}31 \\
0.3 \pm 0.85\end{array}$ & $\begin{array}{c}624 \\
0.2 \pm 0.59\end{array}$ & $\begin{array}{c}71 \\
0.3 \pm 0.79\end{array}$ \\
\hline $\begin{array}{l}\text { Change in yearly hospitalisation rate } \\
\text { n } \\
\text { Mean } \pm S D\end{array}$ & $\begin{array}{c}50 \\
-67.3 \% \pm 60.85\end{array}$ & $\begin{array}{c}20 \\
-87.8 \% \pm 28.73\end{array}$ & $\begin{array}{c}218 \\
-74.3 \% \pm 52.10\end{array}$ & $\begin{array}{c}16 \\
-49.2 \% \pm 80.77\end{array}$ & $\begin{array}{c}268 \\
-73.0 \% \pm 53.79\end{array}$ & $\begin{array}{c}36 \\
-70.7 \% \pm 60.20\end{array}$ \\
\hline $\begin{array}{l}\text { Improvement in AC after omalizumab initiation }{ }^{\dagger} \\
n \\
\text { Yes, } n(\%)\end{array}$ & $\begin{array}{c}74 \\
58(78.4)\end{array}$ & $\begin{array}{c}41 \\
36(87.8)\end{array}$ & $\begin{array}{c}290 \\
142(49.0)\end{array}$ & $\begin{array}{c}29 \\
12(41.4)\end{array}$ & $\begin{array}{c}364 \\
200(54.9)\end{array}$ & $\begin{array}{c}70 \\
48(68.6)\end{array}$ \\
\hline
\end{tabular}

Note: ${ }^{\dagger}$ Only patients with $A C$ at omalizumab initiation are included in the analysis.

Abbreviations: AC, allergic comorbidities; AD, atopic dermatitis; Cl, confidence interval; GETE, Global Evaluation of Treatment Effectiveness; SD, standard deviation; $n$, patients with available data.

limited to a cohort of patients in France, these results are potentially clinically relevant and worthy of further investigation.

In conclusion, in our cohort of SAA patients, presence of $\geq 3 \mathrm{AC}$ was observed in minors and in adults, albeit to a lesser extent, suggesting that this phenotype is persistent throughout life. Omalizumab was shown to be beneficial in all SAA patients, though its effectiveness was greater in patients (minors and adults) with $\geq 3$ AC. Our results also suggest that omalizumab might improve $\mathrm{AC}$ and in particular $\mathrm{AD}$ and food allergies. In future studies on the efficacy of biological treatments for severe asthma, dedicated pre-planned analyses taking into account the presence of multiple AC at baseline should be performed.

\section{Acknowledgments}

The authors would like to thank the patients and investigators participating in this study, and Matrix Consultants for the support provided in the preparation of this manuscript. STELLAIR investigators: M. Agossou (Fort de France), C. Appere de Vecchi (Argenteuil), E. Barbare (Meaux), M. Barbry (Taden), C. Belleguic-Lebreton (Rennes), D. Benhamou (Bois-Guillaume Bihorel), A. Bentaleb (Amiens), A. Blanc (Aix en Provence), P. Bonniaud (Dijon), M. Bourgoin (Paris), J. Brouard (Caen), P-M. Broussier (Bois-Guillaume Bihorel), D. Caimmi (Montpellier), E. Catherinot (Suresnes), R. Chiron (Montpellier), M. Claussner-Paulignan (Forbach), P. CombeCayla (Villefranche de Rouergue), P. Cros (Brest), G. Dauriat (Paris), B. Delaisi (Boulogne-Billancourt), G. Devouassoux (Lyon), T. Didi (Metz-Tessy), A. Didier (Toulouse), S. Dominique (Rouen), P. Dumont (Chauny), S. Dury (Reims), D. Dusser (Paris), M. Fayon (Bordeaux), M. Gainet-Brun (Besançon), G. Garcia (Le KremlinBicêtre), L. Guilleminault (St Pierre de la Réunion), N. Hesse (Rennes), S. Jeandeau (Ste Feyre), V. Jubin 
(Bron), J. Just (Paris), N. Just (Roubaix), P-E. Kelkel (Chambery), A-S. Kerjan (Guingamp), A. Labbe (ClermontFerrand), H. Laize (Sceaux), Y. Laoudi (Aulnay-sous-Bois), M. Larrousse (Toulon), Y. Le Guen (St Grégoire), O. Leleu (Abbeville), G. Letanche (Venissieux), G. Lorillon (Paris), G. Mangiapan (Créteil), E. Marangoni (St Die des Vosges), S. Marchand-Adam (Tours), P. Martin (Metz-Vantoux), C. Maurer (Montfermeil), F. Menivale (Colombiers), B. Mouget (Vandoeuvre les Nancy), D. Muller (Metz), M. Nasr (Vienne), L. Nguyen (Bordeaux), J-P. Oster (Colmar), H. Pegliasco (Marseille), B. Philippe (Pontoise), I. Pin (La Tronche), C. Pison (La Tronche), A. Proust (Nîmes), A. Prudhomme (Tarbes), C. Radu (Strasbourg), A. Rakoto (Chalon sur Saône), C. Rochefort-Morel (Rennes), C. Rolland-Debord (Paris), P. Romand (Contamine sur Arve), P. Roux (Besançon), C. Sattler (Le Kremlin Bicêtre), D. Siret (St Nazaire), C. Taillé (Paris), L. Tetu (Toulouse), A-I. Tiotiu (Vandoeuvre les Nancy), C. Tummino (Marseille), J. Valcke (Vanves), S. Verdier (Perpignan), P. Vigneron (Lorient), J. Virally (Aulnay-sousBois), S. Wanin (Paris), all in France.

\section{Author Contributions}

J. Just, C. Thonnelier, M. Humbert, M. Molimard and L. Mala contributed to data analysis and interpretation. M. Humbert, M. Molimard and L. Mala contribute to the STELLAIR study concept and data acquisition. M. Humbert, J. Just and M. Bourgoin-Heck contributed to patient recruitment. All authors made substantial contributions to conception and design, acquisition of data, or analysis and interpretation of data; took part in drafting the article or revising it critically for important intellectual content; agreed to submit to the current journal; gave final approval of the version to be published; and agreed to be accountable for all aspects of the work.

\section{Funding}

Novartis Pharma.

\section{Disclosure}

Prof. Jocelyne Just reports grants, personal fees from Novartis, during the conduct of the study; grants and/or personal fees from AstraZeneca, Alk-Abello, and Sanofi, outside the submitted work. Dr Celine Thonnelier is an employee of Novartis Pharma SAS, during the conduct of the study. Dr Melisande Bourgoin-Heck reports grants, non-financial support from Novartis, during the conduct of the study; personal fees, non-financial support from Stallergenes and ALK, outside the submitted work. Dr Laurence Mala is an employee of Novartis Pharma S. A.S., during the conduct of the study. Prof. Mathieu Molimard reports personal fees for consultancy from Novartis Pharma, during the conduct of the study. Prof. Marc Humbert reports personal fees, non-financial support from Novartis, during the conduct of the study; grants and/ or personal fees, non-financial support from AstraZeneca, GSK, grants, Merck, Roche, Sanofi, and Teva, outside the submitted work. The authors report no other conflicts of interest in this work.

\section{References}

1. Chung KF, Wenzel SE, Brozek JL, et al. International ERS/ATS guidelines on definition, evaluation and treatment of severe asthma. Eur Respir J. 2014;43(2):343-373. doi:10.1183/09031936.00202013

2. Bourdin A, Fabry-Vendrand C, Ostinelli J, et al. The burden of severe asthma in France: a Case-Control Study using a medical claims database. J Allergy Clin Immunol Pract. 2019;7(5):1477-1487. doi:10.1016/j.jaip.2018.12.029

3. Reddel HK, Bateman ED, Becker A, et al. A summary of the new GINA strategy: a roadmap to asthma control. Eur Respir J. 2015;46 (3):622-639. doi:10.1183/13993003.00853-2015

4. Navines-Ferrer A, Serrano-Candelas E, Molina-Molina GJ, Martin M. IgE-related chronic diseases and anti-ige-based treatments. J Immunol Res. 2016;2016:8163803. doi:10.1155/2016/ 8163803

5. Oettgen HC, Geha RS. IgE regulation and roles in asthma pathogenesis. J Allergy Clin Immunol. 2001;107(3):429-440. doi:10.1067/mai.2001.113759

6. Humbert M, Bousquet J, Bachert C, et al. IgE-mediated multimorbidities in allergic asthma and the potential for omalizumab therapy. J Allergy Clin Immunol Pract. 2019;7(5):1418-1429. doi:10.1016/j. jaip.2019.02.030

7. Hose AJ, Depner M, Illi S, et al. Latent class analysis reveals clinically relevant atopy phenotypes in 2 birth cohorts. J Allergy Clin Immunol. 2017;139(6):1935-1945e1912. doi:10.1016/j. jaci.2016.08.046

8. Zoratti EM, Krouse RZ, Babineau DC, et al. Asthma phenotypes in inner-city children. J Allergy Clin Immunol. 2016;138(4):1016-1029. doi:10.1016/j.jaci.2016.06.061

9. Chervinsky P, Casale T, Townley R, et al. Omalizumab, an anti-IgE antibody, in the treatment of adults and adolescents with perennial allergic rhinitis. Ann Allergy Asthma Immunol. 2003;91(2):160-167. doi:10.1016/S1081-1206(10)62171-0

10. Cusack RP, Sahadevan A, Lane SJ. Qualitative effects of omalizumab on concomitant IgE-mediated disease in a severe asthmatic population: a Real Life Observational Study. QJM. 2016;109(9):601-604. doi:10.1093/qjmed/hcw027

11. Gevaert P, Calus L, Van Zele T, et al. Omalizumab is effective in allergic and nonallergic patients with nasal polyps and asthma. J Allergy Clin Immunol. 2013;131(1):110-116e111. doi:10.1016/j. jaci.2012.07.047

12. Kopp MV, Hamelmann E, Zielen S, et al. Combination of omalizumab and specific immunotherapy is superior to immunotherapy in patients with seasonal allergic rhinoconjunctivitis and co-morbid seasonal allergic asthma. Clin Exp Allergy. 2009;39(2):271-279. doi:10.1111/j.1365-2222.2008.03121.x 
13. Labrosse R, Graham F, Des Roches A, Begin P. The use of omalizumab in food oral immunotherapy. Arch Immunol Ther Exp (Warsz). 2017;65(3):189-199. doi:10.1007/s00005-016-0420-z

14. Li JX, Fan LC, Li MH, Cao WJ, Xu JF. Beneficial effects of omalizumab therapy in allergic bronchopulmonary aspergillosis: a synthesis review of published literature. Respir Med. 2017;122:33-42. doi:10.1016/j.rmed.2016.11.019

15. Masieri S, Cavaliere C, Begvarfaj E, Rosati D, Minni A. Effects of omalizumab therapy on allergic rhinitis: a Pilot Study. Eur Rev Med Pharmacol Sci. 2016;20(24):5249-5255.

16. Penn R, Mikula S. The role of anti-IgE immunoglobulin therapy in nasal polyposis: a pilot study. Am J Rhinol. 2007;21(4):428-432. doi:10.2500/ajr.2007.21.3060

17. Rafi A, Do LT, Katz R, Sheinkopf LE, Simons CW, Klaustermeyer W. Effects of omalizumab in patients with food allergy. Allergy Asthma Proc. 2010;31(1):76-83. doi:10.2500/ aap.2010.31.3304

18. Sheinkopf LE, Rafi AW, Do LT, Katz RM, Klaustermeyer WB. Efficacy of omalizumab in the treatment of atopic dermatitis: a Pilot Study. Allergy Asthma Proc. 2008;29(5):530-537. doi:10.2500/aap.2008.29.3160

19. Vennera Mdel C, Picado C, Mullol J, Alobid I, Bernal-Sprekelsen M. Efficacy of omalizumab in the treatment of nasal polyps. Thorax. 2011;66(9):824-825. doi:10.1136/thx.2010.152835

20. Vignola AM, Humbert M, Bousquet J, et al. Efficacy and tolerability of anti-immunoglobulin E therapy with omalizumab in patients with concomitant allergic asthma and persistent allergic rhinitis: SOLAR. Allergy. 2004;59(7):709-717. doi:10.1111/j.1398-9995.2 004.00550.X

21. Humbert M, Taille C, Mala L, et al. Omalizumab effectiveness in patients with severe allergic asthma according to blood eosinophil count: the STELLAIR Study. Eur Respir J. 2018;51(5):1702523. doi:10.1183/13993003.02523-2017
22. Sese L, Schneider M, Bourgoin M, et al. Asthma with multiple allergic comorbidities is associated with complete response to omalizumab. Clin Exp Allergy. 2019;49(5):733-735. doi:10.1111/ cea. 13373

23. Chipps BE, Zeiger RS, Luskin AT, et al. Baseline asthma burden, comorbidities, and biomarkers in omalizumab-treated patients in PROSPERO. Ann Allergy Asthma Immunol. 2017;119(6):524-532. e2. doi:10.1016/j.anai.2017.09.056

24. Balbino B, Conde E, Marichal T, Starkl P, Reber LL. Approaches to target IgE antibodies in allergic diseases. Pharmacol Ther. 2018;191:50-64.

25. Holgate S, Buhl R, Bousquet J, Smith N, Panahloo Z, Jimenez P. The use of omalizumab in the treatment of severe allergic asthma: a clinical experience update. Respir Med. 2009;103(8):1098-1113. doi:10.1016/j.rmed.2009.03.008

26. Colodenco D, Palomares O, Celis C, Kaplan A, Domingo C. Moving toward consensus on diagnosis and management of severe asthma in adults. Curr Med Res Opin. 2018;34(3):387-399. doi:10.1080/ 03007995.2017.1380617

27. Omalizumab as monotherapy and as adjunct therapy to multi-allergen OIT in food allergic participants (OUtMATCH). ClinicalTrials.gov identifier: NCT03881696. Available from: https:/clinicaltrials.gov/ ct2/show/NCT03881696. Accessed February 16, 2021.

28. Chan S, Cornelius V, Cro S, Harper JI, Lack G. Treatment effect of omalizumab on severe pediatric atopic dermatitis: the ADAPT randomized clinical trial. JAMA Pediatr. 2019;174(1):29-37. doi:10.1001/jamapediatrics.2019.4476

29. Holm JG, Thomsen SF. Omalizumab for atopic dermatitis: evidence for and against its use. G Ital Dermatol Venereol. 2019;154 (4):480-487. doi:10.23736/S0392-0488.19.06302-8

\section{Publish your work in this journal}

The Journal of Asthma and Allergy is an international, peer-reviewed open-access journal publishing original research, reports, editorials and commentaries on the following topics: Asthma; Pulmonary physiology; Asthma related clinical health; Clinical immunology and the immunological basis of disease; Pharmacological interventions and new therapies. The manuscript management system is completely online and includes a very quick and fair peer-review system, which is all easy to use. Visit http://www.dovepress.com/testimonials.php to read real quotes from published authors. 